\title{
Gender and Age Differences in Choice of Holiday Destination: Case of Langkawi, Malaysia
}

\author{
An Nur Nabila Ismail ${ }^{1}$, Yuhanis Abdul Aziz ${ }^{1}$, Norazlyn Kamal Basha ${ }^{1}$, \& Anuar Shah Bali Mahomed ${ }^{1}$ \\ Correspondence: Yuhanis Abdul Aziz, School of Business and Economics, Universiti Putra Malaysia, Serdang, \\ Selangor, Malaysia. E-mail: yuhanis@upm.edu.my
}

Received: July 31, $2021 \quad$ Accepted: August 22, $2021 \quad$ Online Published: September 19, 2021

doi:10.5539/ass.v17n10p1 URL: https://doi.org/10.5539/ass.v17n10p1

\begin{abstract}
While gender and age are considered as important demographic factors in tourism segmentation, lack of attention has been given by tourism researchers. Moreover, gender and age analysis within tourism studies are still limited, particularly in the context of choice of destination. The aim of this paper is to examine the role of gender and age in determining the destination choice. Langkawi has been chosen as a location for the study due to its popularity among the local and international tourist. Survey questionnaire is used as a tool for data collection. A total of 529 Langkawi holidaymakers participated in the study. T-test and ANOVA has been employed to analyse the data. The findings indicate that gender and age both influence Langkawi being chosen as a holiday destination. Male and female consumers place different emphasis on the selection of Langkawi as a destination of choice. These findings suggest that tourism advertisers and destination promoters need to be aware of different needs and wants of both males and females. However, tourists of different ages evaluate Langkawi similarly, which marketers can use a variety of promotion packages for all age group. The study's practical implications and limitations are discussed.
\end{abstract}

Keywords: gender, age, destination choices, Langkawi

\section{Introduction}

Tourism is one of the industries that grow rapidly, and it became one of income generator to many countries (Ababneh, 2013). Malaysia becomes one of the favourite tourism destinations among the tourists due to its natural beauty. Moreover, Malaysia itself is located at a very strategic place which provides easy access to international tourist. Malaysia is also very rich in nature (Karim, 2014). A variety of tourism destination offers a lot of attraction in term of products and facilities which may attract more tourists to visit. A wide range of tourism destinations also provide opportunity for travellers to choose their destination depending on their preferences and purposes of visit. Based on WTTC (2019) report, travel and tourism have contributed approximately RM 190.3 billion (USD 47.2 billion) in 2018, charting a 2.6\% growth compared to 2017.

Due to its importance in income generation to the country, Ministry of Tourism and Culture Malaysia (MOTAC) has taken a serious action in promoting Malaysia as one of the top destinations while promoting its attractiveness (Zainuddin, Radzi, \& Zahari, 2016). Numbers of tourists arrival in Malaysia is keep increasing year by year as shown in table 1 and Malaysia have received 26.10 million of tourist arrival in year 2019 and earn RM82.2 billion from tourism activities (Tourism Malaysia, 2020). This tourism growth has enabled Malaysia to position herself as one of competitive countries whereby Malaysia has been ranked at 26th place out of 136 countries (New Straits Times, 2017). In addition, World Economic Forum, WEF (2017) also claimed that Malaysia has done a lot of upgrading in term of technology, facilities as well as international readiness as a preparation to receive more tourists. Due to this improvement, tourism Malaysia is continuously growing and Malaysia is also ready to receive more tourists to visit Malaysia.

Table 1. Tourist Arrivals and Receipts to Malaysia

\begin{tabular}{ccc}
\hline Year & Arrivals & Receipts (RM) \\
\hline 2019 & 26.10 million & 86.1 billion \\
2018 & 25.83 million & 84.1 billion \\
2017 & 25.95 million & 82.1 billion \\
2016 & 26.76 million & 82.1 billion \\
\hline
\end{tabular}




\begin{tabular}{lll}
\hline 2015 & 25.72 million & 69.1 billion \\
2014 & 27.44 million & 72.0 billion \\
2013 & 25.72 million & 65.4 billion \\
2012 & 25.03 million & 60.6 billion \\
2011 & 24.71 million & 58.3 billion \\
2010 & 24.58 million & 56.5 billion \\
2009 & 23.65 million & 53.4 billion \\
2008 & 22.95 million & 49.6 billion \\
2007 & 20.97 million & 53.4 billion \\
2006 & 17.55 million & 36.3 billion \\
\hline
\end{tabular}

(Source: Tourism Malaysia, 2020)

Langkawi is one of the beautiful places in Malaysia which is gifted with 99 stunning islands that has strong character to attract tourist to visit. Langkawi is one of the most popular destinations in Malaysia. According to Lembaga Pembangunan Langkawi, LADA (2020), Langkawi have received around 3.92 million of tourist arrival in year 2019 which reported $8 \%$ increment as compared to 2018 which is 3.62 million of tourist arrival. Tourist arrival in Langkawi is increasing since 2011 until 2019 as illustrated in Table 2. Moreover, Langkawi's progressive situation has been supported by other factors such as AirAsia provision of direct flight from Shenzen to Langkawi whereby it assist Langkawi to boost and gain more international tourists from China starting $9^{\text {th }}$ August 2017 (The Star Online, 2017).

Table 2. Tourist Arrivals to Langkawi

\begin{tabular}{ll}
\hline Year & Arrivals \\
\hline 2019 & 3.92 million \\
2018 & 3.62 million \\
2017 & 3.67 million \\
2016 & 3.63 million \\
2015 & 3.62 million \\
2014 & 3.60 million \\
2013 & 3.41 million \\
2012 & 3.06 million \\
2011 & 2.81 million \\
\hline
\end{tabular}

(Source: LADA, 2020)

Langkawi has becomes one of the top destinations in Malaysia due to its amazing attractions such as beautiful beaches with clear crystal water, tropical weather, flora and fauna, historical places, variety outdoor activities and also duty-free shopping centre (Omar, Othman, \& Mohamed, 2014). Langkawi is also very famous with their natural attributes and beautiful landscape including rainforests, mountains, beaches and its coral reefs (Aliman, Hashim, Wahid, \& Harudin, 2016). Due to the diversity of attractions in term of nature, Langkawi has aura to attract tourists who love the nature. Furthermore, Langkawi also offered heritage value in terms of its uniqueness of historical places such as Makam Mahsuri, Beras Terbakar and Tasik Dayang Bunting. For those who love outdoor activities, Langkawi also presents countless activities such as underwater world, Langkawi Skycab, Langkawi Wildlife and Bird Paradise, water activities and Skytrex Langkawi.

Past studies in tourism have explored the similarities and differences in respondent profile such as gender, age, attitudes and education level with other perspective of tourism such as sustainability, information sources, tourist expectation, perception and many more. However, limited study was found to concentrate on differences of respondent profile in deciding a destination choice. Thus, this study attempts to explore if there are any differences in terms of destination choice whereby it will look to two different perspectives which is gender and age. Moreover, there is limited study that focusing in Langkawi, Malaysia even though Langkawi is popular destination among tourists. Therefore, the objective of this paper is to examine the role of gender and age in determining the destination choice of Langkawi. Hence, this research paper will provide insights into the different perspective of gender and age with regard to destination choice in Langkawi. 


\section{Literature Review}

\subsection{Destination Choice}

Tourists develop a psychological choice set of comparing destinations before finally selecting a place to visit. The choice of destination is depending on two factors which is internal and external factor (Karl, Reintinger \& Schmude, 2015). Internal factor is also known as individual factor which is the factor that are related to individual characteristic such as motivation to visit, taste, travel constrain, past experience and traveller personality. However, external factor is an environmental factor that will affect a choice of destination one particular traveller such as the ability of information, socio culture, influencer (family or friends) and lifestyle (Mutinda \& Mayaka, 2012; Karl, Reintinger, \& Schmude, 2015). In order to choose one particular destination, travellers will highly involve in decision making process. According to Karl, Muskat and Ritchie (2020), decision making process will involve several stages that need to be go through by tourists before they decide to choose one final holiday destination. In order to gather the information and evaluate them, tourists will spend more time on it (Thiumsak \& Ruangkanjanases, 2016).

Destination choice has been tested in numerous studies. Pan, Rasouli and Timmermans (2021) has examined the choice of destination among tourist which focusing on how destination images of tourists' social network can encourage the tourist choice behaviour. The finding indicates that destination image of tourists' social network help to enhance the tourists knowledge about holiday destination which it has influence the choice of destination. On other hand, study by Mussalam and Tajeddini (2016) revealed that, travel attraction, infrastructure and facilities influenced the traveller in choosing Switzerland as their destination holidays. Research by Lim and Hector (2021) was explored on what are the factors that been considered by family when choosing a destination during evacuation period during Typhoon Haiyan. There are two destination that categorized by Lim and Hector (2021) study which is public shelter and family or friends' house. The finding reveals that gender, income, material status and number of family members are factors that influence the choice of destination.

A study by Mutinda and Mayaka (2012) found that Nairobi residents motivated to choose local tourism destination because of familiarity, economic situation, the availability of information, travel arrangement services, personal safety, for leisure and relaxation as well as cultural consideration. Tomic, Konacevic, Berber and Milic (2014) claimed that there are seven factors that influence young travellers which is student from Esbjerg to choose Europe as their destination holiday. Among the factors are having fun, the availability to information, meet new people, exploring something new, variety of shopping place, easy and reasonable price for travel package and variety of outdoor activities.

\subsection{Gender Influence}

Research on the demographic profile is widely discussed in previous study. The profiles that are frequently used are gender, age, level of income, occupation and marital status. However, gender is one of the common factors that has been examined as one of the factors that give effect to certain study such as behavioural intention (Kim, Cho, \& Kim, 2019), tourists' expectation (Wang, Qu, \& Hsu, 2016) and young tourists' perception (Carr, 2011). According to World Health Organization (WHO), gender refer to the two group of social constructed personalities which is male and female, and these two groups have a significant different in term of norms and behaviour which can be seen through communication, decision making, relative power as well as relationship.

Kim, Cho and Kim (2019) examined how gender of customer influence the relationship between wine promotion (promotion menu, based information about wine, customer service, human sale) and customer satisfaction. The finding reveals that there are significant different between male and female towards wine promotion and customer satisfaction. Based on the finding it appears that gender was positively influence by promotion menu. Kim, Lehto and Morrison (2007) examined the gender difference in search the travel information via online. This study was examining the differences between male and female in term of online travel website functionality, content preferences and search behaviour. The study found that gender has a significant different whereby females tent to use variety of online and offline sources of information about destination and become the one who decide the travel destinations.

Study by Wang, Qu and Hsu (2016) has examined the differences between male and female tourists from China in term of their expectation towards Macao as a travel destination. The study was conducted based on cognitive image which is advertising and word of mouth. The result shows that there are significant difference between gender and cognitive image. Male are more likely to be influenced by destination advertising whereas female thought word of mouth is more valid and trusted. Research by Carr (2011) has discovered gender differences in young traveller perception of danger in London whereby danger are assessed by considering the safety, relaxed, risk, susceptible and threatened while the tourists in London city. The result indicates that there are different idea 
and perception between male and female in term of the level of dangerous in London city. Female claims that London is dangerous as compared to male. Male feel less dangerous when they at public spaces. The result also shows that there is no significant difference between daytime and night by male whereas female claims that night-time are more dangerous as compared to daytime. Considering the lack of research on the effect of gender on the destination choice, therefore the following hypothesis is suggested:

H1: There is significant difference in gender on destination choice of Langkawi

\subsection{Age Influence}

Age also play an important role when the study would like to measure the differences between groups in one particular scenario. In this case, the current study would like to explore the differences of various age groups in choosing holiday destination. According to Oxford Dictionary, age is referred to the length of period that an individual has lived, or a thing has lasted. Age become quite popular topic in tourism research such as Bojanic (2011) studied the shopping expenditures and a study by Jonsson and Devonish (2008) focused on travel motivation. On other hand, study by Basaric et al., (2016) explored on travel behaviour.

A study by Jonsson and Devonish (2008) investigated whether there are any differences in term of travel motivation with nationality, gender and age among traveller who visit Caribbean Island of Barbados. There are four main travel motivations that been focused in this study which is culture, pleasure-seeking, relaxation and physical motivation. The result shows that, there are significant difference between nationality and age. However, gender did not significantly impact travel motivation to visit Barbados. Similarly, Basaric et al., (2016) have identified the travel characteristics in Novi Sad with regards to gender and age. Through its finding, it shows that there are significant different between eight age group. Each age group have different travel characteristics. As an example, age group range from 19 to 25 years old make a longest journey in travel compare to other groups. On the other hand, Bojanic (2011) examined the key target market for shopping mall in United State related to age and family situation which is marital status and number of children. The result found that, there are no significant difference between age and marital status towards shopping expenditure. However, having children does affect the shopping expenditures. Due to the argument of the age-significant difference, the current research proposes the following hypothesis:

H2: There is a significant difference in age on destination choice of Langkawi

\section{Methodology}

The aims of this study is to explore the role of gender and age in determining Langkawi as the destination choice. This paper uses quantitative approach and using non-probability sampling technique. The target population are tourists visiting Langkawi as their choice of holidays destination. A set of questionnaires are filled up by tourists whereby it took approximately 5 to 10 minutes to complete.

\subsection{Measurement}

This questionnaire was divided into two sections which is respondent profiles and destination choice. There are 18 questions on the destination choice part which all the question is related to Langkawi. The dimension of each construct is adapted from several past studies such as Seddighi and Theocharous (2001); Kozak (2000); Seyidov and Adomaitiene (2016); and Phau, Quintal \& Shanka (2014) and all the items was measured using likert scale which is from 1 (strongly disagree) to 5 (strongly agree).

Lastly, there are 6 questions for respondent's profile in order to understand the demographic characteristics of respondents. The questions are covering items such as gender, age, nationality that divided into two group which is Malaysian and non-Malaysian, time visited Langkawi, sources of information about Langkawi. The descriptive summary of these finding is reported in table 3 and 4. This study consisted of 529 respondents which includes local and international tourists. The questionnaire asked about the factors that influenced them to choose Langkawi as their holiday destination.

\subsection{Data Analysis}

After all data has been collected, data analysis is analysed using Statistical Package Social Science (SPSS) software. Firstly, the data was analysed using the descriptive analysis in order to disclose the respondent profile. Then, t-test was run for gender and ANOVA test was employed for age to compare means between groups.

\section{Result and Discussion}

\subsection{Profile of Respondents}

The demographic profile is shown in Table 3 . About $61.2 \%$ of the participant are female while male participant is 
$38.8 \%$. For age, $21.4 \%$ are aged between 18 to 24 years, $24.4 \%$ are 25 to 30 years, $19.1 \%$ are 31 to 34 years, $20.8 \%$ are 35 to 40 years while for 41 years and above are $14.4 \%$. For nationality, there are inbound and outbound tourists that involve in this study. 407 respondents are from Malaysia which comprise of 167 Malay, 153 Chinese, 85 Indian and 2 are others. On other hand, 122 respondents are international tourists which are come from 15 countries which is Poland (7), Denmark (6), United Kingdom (6), France (6), Netherlands (7), Russian (6), Australia (9), Canada (11), Egypt (11), China (17), Qatar (10), United Arab Emirates (6), Brunei (7), Singapore (6) and Indonesia (7).

Respondents also have been asked on how many time they have visited Langkawi and surprisingly, all of them have visited Langkawi before. Around $27.8 \%$ of respondents have visited Langkawi for 4 times, followed by $25.3 \%$ (3 times) and 23.4\% have visited Langkawi 2 times. 124 respondents also declared that they have visited Langkawi more than 5 times.

New platform which is digital platform became an important source when traveller want to choose their travel destination. 457 respondents claimed that, they obtain the information about Langkawi via social media (20.9\%) which is Facebook, Instagram as well as Twitter; Word of mouth (17.9\%), website (15.7\%), travel agency $(13.7 \%)$, blog $(13.7 \%)$ and recommendation from family and friends (12\%) also become a platform to traveller in finding the information about Langkawi. A traditional platform such as magazine (0.4\%), newspaper (1.3\%), television $(1.8 \%)$ and billboard $(1.6 \%)$ appear to have less impact in providing the information about Langkawi.

Table 3. Profile of respondents

\begin{tabular}{|c|c|c|}
\hline Variable & Study & Percent \\
\hline \multicolumn{3}{|l|}{ Gender } \\
\hline Male & 205 & 38.8 \\
\hline Female & 324 & 61.2 \\
\hline \multicolumn{3}{|l|}{ Age } \\
\hline $18-24$ & 113 & 21.4 \\
\hline $25-30$ & 129 & 24.4 \\
\hline $31-34$ & 101 & 19.1 \\
\hline $35-40$ & 110 & 20.8 \\
\hline 41 years and above & 76 & 14.4 \\
\hline \multicolumn{3}{|l|}{ Nationality } \\
\hline \multicolumn{3}{|l|}{ Malaysian } \\
\hline Malay & 167 & 31.6 \\
\hline Chinese & 153 & 28.9 \\
\hline Indian & 85 & 16.1 \\
\hline \multicolumn{3}{|l|}{ Non-Malaysian } \\
\hline Poland & 7 & 1.3 \\
\hline Denmark & 6 & 1.1 \\
\hline UK & 6 & 1.1 \\
\hline France & 6 & 1.1 \\
\hline Netherlands & 7 & 1.3 \\
\hline Russian & 6 & 1.1 \\
\hline Australia & 9 & 1.7 \\
\hline Canada & 11 & 2.1 \\
\hline Egypt & 11 & 2.1 \\
\hline China & 17 & 3.2 \\
\hline Qatar & 10 & 1.9 \\
\hline UAE & 6 & 1.1 \\
\hline Brunei & 7 & 1.3 \\
\hline Singapore & 6 & 1.1 \\
\hline Indonesia & 7 & 1.3 \\
\hline
\end{tabular}




\begin{tabular}{ccc}
\hline & How many times did you travel to Langkawi? & 23.4 \\
2 times & 124 & 25.3 \\
3 times & 134 & 27.8 \\
4 times & 147 & 23.4 \\
\hline More than 5 times & 124 & 20.9 \\
\hline \multicolumn{1}{c}{ How did you get information about Langkawi? } & 0.4 \\
Social Media & 457 & 1.3 \\
Magazine & 8 & 1.8 \\
Newspaper & 29 & 17.9 \\
Television & 40 & 1.6 \\
Word of Mouth & 391 & 13.7 \\
Billboard & 36 & 14.6 \\
Blog & 300 & 15.7 \\
Travel Agency & 318 & 12.0 \\
\hline
\end{tabular}

Respondent are also asked to rank which sources of information are important to them before they decide to choose Langkawi as their holiday destination. Based on the finding, there are slightly different view between new and old platform. As shown in table 4, most of the respondents rate new digital platform as more important to them in order to gather the information about Langkawi. The social media, word of mouth and travel agency become very important sources where by each of the get 50.9\%, $45.0 \%$ and $52.7 \%$ respectively. Respondent also rate travel blog (51.6\%), website (52.7\%) and recommendation from family and friends (45.6\%) are important sources to them. Magazine and newspaper are not important at all to the traveller and television and billboard also not important.

From here, it can be concluded that the traditional platform of advertising is less relevant to the travellers and marketers should choose the latest technology and new marketing technique in order to advertise the holiday destination to potential traveller. Due to the advance in technology, most of the travellers choose a very easy, less effort and less costly platform such as online digital based to find the information that they needed and make a decision according to their preferences.

Table 4. Sources of Information

\begin{tabular}{cccccc}
\hline Source of Information & 1 & 2 & 3 & 4 & 5 \\
\hline Social Media & - & - & - & $49.1 \%$ & $50.9 \%$ \\
Magazine & $57.3 \%$ & $34.8 \%$ & $7.9 \%$ & - & - \\
Newspaper & $56.0 \%$ & $40.8 \%$ & $3.2 \%$ & - & - \\
Television & $45.9 \%$ & $54.1 \%$ & $2.3 \%$ & $51.2 \%$ & $45.0 \%$ \\
Word of Mouth & - & $1.5 \%$ & - & - & - \\
Billboard & $40.8 \%$ & $59.2 \%$ & - & $47.6 \%$ & $48.8 \%$ \\
Travel Blog & - & - & - & $52.7 \%$ & $47.3 \%$ \\
Travel Agency & - & - & $3.0 \%$ & $45.6 \%$ & $51.4 \%$ \\
Website & - & - & & 5
\end{tabular}

Note: 1: Not important at all; 2: Not important; 3: Neutral; 4: Important; 5: Very Important

\subsection{T-test Result of Significant Difference of Gender on Destination Choice}

The current study uses T-test analysis to examine the significant differences between gender on the destination choice of Langkawi. According to Fisher (1973), the acceptable value of T-test is the cut-off value (t-value) are more than 1.96 and the significant value (p-value) should be less than 0.05. As shown in table 5, the result from T-test analysis indicates that, there are significant difference between male and female in factor of choosing destination choice $(t=4.811, p=0.000)$. Based on the mean value, it indicates that male (mean $=83.75)$ was found to be more concerned when selecting the destination of choice as compared to female ( $m e a n=82.04$ ). 
Table 5. Analysis of T-test

\begin{tabular}{ccccccccc}
\hline Variable & Gender & $\mathrm{N}$ & Mean & $\mathrm{t}$ & $\mathrm{df}$ & Sig. (2 tailed) & Hypothesis & Results \\
\hline \multirow{2}{*}{ Destination Choice } & Male & 205 & 83.75 & \multirow{2}{*}{4.811} & 527 & .000 & H1 & Supported \\
& Female & 324 & 82.04 & & & & & \\
\hline
\end{tabular}

\subsection{ANOVA Result of Significant Difference of Age on Destination Choice}

For the current study, there are 5 different age group that has been examined towards the factor in choosing Langkawi as destination choice. ANOVA analysis has been used to see if there any significant difference between age on the destination choice. The results indicate that, there is no significant difference between age group on factor choosing Langkawi as travel destination. The value form ANOVA test are t-value is 1.747 ( $\leq$ $1.96)$ and p-value is $0.138(\leq 0.05)$. The result is shown in table 6 .

Table 6. Analysis of ANOVA

\begin{tabular}{ccccccccc}
\hline Variable & Age & N & Mean & Std. Deviation & F & Sig. & Hypothesis & Results \\
\hline & $18-24$ & 113 & 82.35 & 4.08 & & & & \\
Destination & $25-30$ & 129 & 82.81 & 4.15 & & & & Not Supported \\
Choice & $31-34$ & 101 & 83.06 & 3.87 & 1.747 & .138 & H2 & \\
& $35-40$ & 110 & 82.09 & 4.30 & & & & \\
\hline
\end{tabular}

\section{Discussion, Implications, Limitations and Future Research}

Based on data analysis and result obtained, the findings are aligned with past researches. Firstly, it is verified that there is a significant different between gender and destination choice. This finding is parallel with the study held by Kim, Cho and Kim (2019); Wang, Qu and Hsu (2016); and Carr (2011) where past research also found that, there are significant different between male and female. As mention by Kim, Lehto and Morrison (2007), females tent to use variety of sources of information about destination before they make decision. Thus, due to this finding, the propose hypothesis (H1) is accepted.

Second objective was to investigate if there is any significant different between age and destination choice. This objective contains some mixed findings where some studies found there are significant different, and some studies claimed that there are no significant different. The current study shows that opposite result with the study held by Jonsson and Devonish (2008); and Basaric et al., (2016). The current result show that there are no significant different between age and factor in choosing destination choice and this can be supported by the study from Bojanic (2011) which they also found that there are no significant different between age and family situation. Thus, the second hypothesis is rejected.

\subsection{Implications}

The finding obtained in this study have an implication to researcher as well as to marketers. For researcher, this study provides a better understanding in term of the differences respondent behaviour towards the choice of destination. Gender was found to be different in term selecting the destination. Male was found to be more concerned when selecting the destination of choice as compared to female. Thus, this has signal to us that, specific marketing strategies can be developed to further entice the male in assisting them during decision making process. On the other hand, more focus need to be placed to understand further needs and want by female tourists. This study also contributes some knowledge to the marketers who involve in tourism field. Marketers should wisely choose the medium of advertising in order to make sure that the advertising can reach to the right people. Marketers also need to identify the target market that might be their potential customers. Marketers should also plan to offer variety of attractions at the destination so that it can attract any gender from different age group.

\subsection{Limitation and Future Research}

There are some limitations in this study. This study only focusses on one particular destination which is Langkawi. The attraction in Langkawi might be different in another place thus may influence on the selection factors on the destination choice. Thus, future research can be expanded by investigating the role of gender and age at another place and so that comparison can be provided. From that, it will give deeper understanding of traveller behaviour according to two or more different holiday destinations. This study also focusses only two 
demographic factors which is gender and age as main focus thus, did not take into considerations on other demographic factors such as education level, income level, occupation and family size as consideration. Education level, income level, occupation and family size also could play an important role when deciding the destination choice because it will reflect to tourist's behaviour. Thus, future research is recommended to include other demographic factor and perhaps it will gain accurate findings. Finally, the research design only focusses on quantitative and did not take into consideration on the qualitative part. Qualitative research can assist researcher to find out specific need by the traveller when deciding a holiday destination. Thus, it is suggested for future research to consider qualitative method to gain more insight into this.

\section{References}

Ababneh, M. (2013). Service quality and its impact on tourist satisfaction. Interdisciplinary Journal of Contemporary Research in Business, 164-177. Retrieved from https://ssrn.com/abstract=3633075

Aliman, N. K., Hashim, S. M., Wahid, S. D. M., \& Harudin, S. (2016). Tourists' satisfaction with a destination: An investigation on visitors to Langkawi Island. International Journal of Marketing Studies, 8(3), 173-188. https://doi.org/10.5539/ijms.v8n3p173

Basaric, V., Vujicic, A., Simic, J. M., Bogdanovic, V., \& Saulic, N. (2016). Gender and age differences in the travel behavior-a Novi Sad case study. Transportation research procedia, 14, 4324-4333. https://doi.org/10.1016/j.trpro.2016.05.354

Bernama. (2017, July 11). AirAsia's Shenzhen-Langkawi route starts Aug 9. Retrieved from https://www.thestar. com.my/business/business-news/2017/07/11/airasias-shenzhen-langkawi-route-starts-aug-9/

Bojanic, D. C. (2011). The impact of age and family life experiences on Mexican visitor shopping expenditures. Tourism Management, 406-414. https://doi.org/10.1016/j.tourman.2010.03.012

Carr, N. (2011). An Exploratory Study of Gendered Differences in Young Tourists Perception of Danger within London. Tourism Management, 22, 565-570. https://doi.org/10.1016/S0261-5177(01)00014-0

Costa, C. B. (2017). 'Emotional' Female Managers: How Gendered Roles Influence Tourism Management $\begin{array}{llllll}\text { Discourse. Journal of Hospitality and Tourism Management, } & 33,\end{array}$ https://doi.org/156.10.1016/j.jhtm.2017.09.011

Dass, F. (2017, April 6). Malaysia ranked 26th most competitive tourism destination by WEF. Retrieved from https://www.nst.com.my/news/2017/04/227737/msia-ranked-26th-most-competitive-tourism-destination-we $\mathrm{f}$

Fisher, R. (1973). Statistical methods for research workers. New York: Hafner Publishing.

Jonsson, C., \& Devonish, D. (2008). Does nationality, gender, and age affect travel motivation? A case of visitors to the Caribbean island of Barbados. Journal of Travel \& Tourism Marketing, 25(3-4), 398-408.

Karim, A. Z. (2014). Tourism in Malaysia: Problems and prospects in contex to socio-cultural and environment. South Asia Anthropologist, 119-128. Journal of Cotemporary Research in Business, 164-177.

Karl, M. R. (2015). Reject or select: Mapping destination choice. Annals of Tourism Research, 48-64. https://doi.org/10.1016/j.annals.2015.06.003

Karl, M., Muskat, B., \& Ritchie, B. W. (2020). Which travel risks are more salient for destination choice? An examination of the tourist's decision-making process. Journal of Destination Marketing \& Management, 18, 100487. https://doi.org/10.1016\%2Fj.jdmm.2020.100487

Karl, M., Reintinger, C., \& Schmude, J. (2015). Reject or select: Mapping destination choice. Annals of Tourism Research, 54, 48-64. https://doi.org/10.1016/j.annals.2015.06.003

Kim, D. Y., Lehto, X. Y., \& Morrison, A. M. (2007). Gender differences in online travel information search: Implications for marketing communications on the internet. Tourism management, 28(2), 423-433. https://doi.org/10.1016/j.tourman.2006.04.001

Kim, W. H., Cho, J. L., \& Kim, K. S. (2019). The relationships of wine promotion, customer satisfaction, and behavioral intention: The moderating roles of customers' gender and age. Journal of Hospitality and Tourism Management, 39, 212-218. https://doi.org/10.1016/j.jhtm.2019.03.001

Kozak, M. (2000). Comparative analysis of tourist motivations by nationality and destinations. Tourism Management, 221-232. https://doi.org/10.1016/S0261-5177(01)00090-5

Langkawi Development Authority. (2020). Retrieved May 18, 2020, from Tourism Langkawi: www.lada.gov.my 
Lim, M. B. B., \& Hector, R. L. J. (2021). Evacuation destination choice behaviour of households in Eastern Samar, Philippines during the 2013 Typhoon Haiyan. International Journal of Disaster Risk Reduction, 56, 102137. https://doi.org/10.1016/j.ijdrr.2021.102137

Mussalam, G. Q., \& Tajeddini, K. (2016). Tourism in Switzerland: How perceptions of place attributes for short and long holiday can influence destination choice. Journal of Hospitality and Tourism Management, 18-26. https://doi.org/10.1016/j.jhtm.2015.09.003

Mutinda, R., \& Mayaka, M. (2012). Application of destination choice model: Factor influencing domestic tourist destination choice among residents of Nairobi, Kenya. Tourism Management, 1593-1597. https://doi.org/10.1016/j.tourman.2011.12.008

New Straits Times. (2017, November 27). Langkawi has to be protected from ill effects of mass tourism. Retrieved from https://www.nst.com.my/opinion/letters/2017/11/307867/langkawi-has-be-protected-ill-effe cts-mass-tourism

Omar, S. I., Othman, A. G., \& Mohamed, B. (2014). The tourism life cycle: An overview of Langkawi Island, Malaysia. International Journal of Culture, Tourism and Hospitality Research, 272-289. https://doi.org/10.1108/IJCTHR-09-2013-0069

Pan, X., Rasouli, S., \& Timmermans, H. (2021). Inverstigating tourist destination choice: Effect of destination image from social network members. Tourism Management, $83,104217$. https://doi.org/10.1016/j.tourman.2020.104217

Phau, I., Quintal, V., \& Shanka, T. (2014). Examining a consumption values theory approach of young tourists toward destination choice intentions. International Journal of Culture, Tourism and Hospitality Research. https://doi.org/10.1108/IJCTHR-12-2012-0090

Seddighi, H. R., \& Theocharous, A. L. (2002). A model of tourism destination choice: a theoretical and empirical analysis. Tourism management, 23(5), 475-487. https://doi.org/10.1016/S0261-5177(02)00012-2

Seyidov, J., \& Adomaitienè, R. (2016). Factors influencing local tourists' decision-making on choosing a destination: A case of Azerbaijan. Ekonomika, 95(3), 112-127. https://doi.org/10.15388/Ekon.2016.3.10332

Thiumsak, T., \& Ruangkanjanases, A. (2016). Factor influencing international visitors to revisit Bangkok, Thailand. Journal of Economic, Business and Management, 4(3), 220-230. https://doi.org/10.7763/JOEBM.2016.V4.394

Tomic, N., Kovacevic, B., Berber, N., \& Milic, N. (2014). Factors Influencing the Motivation of Young People When Choosing a City Destination in Europe - a Case Study From Esbjerg (Denmark). European Research, 414-428.

Tourism Malaysia. (2020). Malaysia Tourism Statistics. Tourism Malaysia.

Wang, C., Qu, H., \& Hsu, M. K. (2016). Toward an integrated model of tourist expectation formation and gender difference. Tourism Management, 58-71. https://doi.org/10.1016/j.tourman.2015.10.009

World Economic Forum (WEF). (2017). The Travel and Tourism Competitiveness Report - Travel and Tourism at a Tipping Point.

World Travel \& Tourism Council. (2019). Travel and Tourism Economic Impact 2018 - Malaysia.

Zainuddin, Z., Radzi, S. M., \& Zahari, M. S. M. (2016). Perceived destination competitiveness of Langkawi Island, Malaysia. Social and Behavioral Sciences, 390-397. https://doi.org/10.1016/j.sbspro.2016.05.190

\section{Copyrights}

Copyright for this article is retained by the author(s), with first publication rights granted to the journal.

This is an open-access article distributed under the terms and conditions of the Creative Commons Attribution license (http://creativecommons.org/licenses/by/4.0/). 